\title{
Raw Material Analysis control of SMBE Slipper Producer using Economic Order Quantity
}

\author{
Sabarudin Ahmad ${ }^{1 *}$, Mualim Mualim ${ }^{1}$, Sugeng Purwoko ${ }^{1}$, and Rifky Yusron ${ }^{2}$ \\ ${ }^{1}$ Department of Industrial Engineering, University of Trunojoyo Madura, Bangkalan, Indonesia \\ ${ }^{2}$ Department of Mechanical Engineering, University of Trunojoyo Madura, Bangkalan, Indonesia
}

\begin{abstract}
The growth of small-medium business enterprise in Indonesia is getting faster in decade, including small-medium business enterprise who produce slippers. SISCO is one of small-medium business enterprise who produce slipper. They must keep tight with market requirement. The supply of raw materials in a small-medium business enterprise is one of the important during production process. In some case their products are mismatch number from market demand. It can be worse if there a mismatch between raw materials ordering schedule from supplier and market demand from consumers. One of this problem requires Economic Order Quantity method as a solution, because during slippers production we have to order from supplier. Inventories are materials stored as raw materials, then they processed be finish product. To find out inventory, one of the inventory models used is the economic order quantity model. This method seeks to achieve the minimum possibility of inventory levels and lower costs and better quality. Economic Order Quantity method calculation based on raw material inventory control in SISCO slipper brand. Optimum monthly cost is IDR $5.293 .541,03$ to meet supply materials.
\end{abstract}

Keywords: EOQ, Inventory control, Market demand, SMBE.

\section{Introduction}

Raw material inventory in small-medium business enterprise (SMBE) is a key to conducting production process, if inventories are low, production process will get trouble. Based on that statement, production line of SMBE highly depend on their inventory[1]. When determining demand of raw materials in a SMBE, we need an amount of production volume. Based on these considerations, we can calculate it the amount of raw materials used in a period [2], [3]. When we want to minimize inventory costs in a period, we must know matching data between actual supply raw materials with raw materials using in a period. This can be called efficiency of raw material inventory which can be useful to minimize costs to be incurred. If the raw material inventory is overstock, the costs will be higher[4].

Overstock raw material in inventory, lead to loss for SMBE especially in financial statement. These will have any impact such less profits and lead to other costs like storage costs for raw materials and maintenance costs for raw materials[5]. This problem will have an impact on storage costs and affect the location of the raw materials and the storage layout. In an SMBE, when you want to produce goods, you must look at how to produce goods and the amount of inventory so that there is no overstock in the procurement of raw materials. In addition, the SMBE must consider the surge that will occur by market demand[6].

\footnotetext{
* Corresponding author : sabarutm@gmail.com
}

SMBE must prepare if additional raw materials are needed[7].An SMBE can make a profit by maximizing sales and minimizing inventory costs. SISCO is an SMBE brand that is engaged in producing slippery. Products produced at the SISCO brand SMBE are often not in accordance with the number of requests from consumers[8]. This problem is also added to the schedule of ordering raw materials from consumers. The problem with this raw material requires a solution using the EOQ (Economic Order Quantity) method because in making these slippery you have to order from a supplier.[9]

In this condition, the control of raw materials at SISCO must be controlled in order to prevent shortages and control the slightest risk in producing slippery. Even will minimize the cost of raw material inventory in every slippery production. The achievement of the desired target in controlling raw material inventory at SMBE SISCO can be used with the EOQ method so that it is able to calculate and control the amount of raw material inventory. The raw materials for making these slippery are EVA sponge, base, glue, slippery and plastic. The process of making these slippery consists of several stages for later slippery ready for sale. The stages of making these slippery include gluing the slippery shape, gluing with a thin layer, pressing, sanding, punching holes for clamps and installing slippery straps. At SMBE, most of these slippery still produce using manual tools in the process. 


\section{Methods}

This research is a case study type. This research conducted incentive, detailed and in-depth manner on the object of the organism institution or certain symptoms to be observed. This type of research in this analysis uses secondary data collected directly from company. This research discusses case regarding raw materials supplies in SISCO slippery brand. The discussion in this study uses data on raw materials supplies of sandals, such as sponge-EVA, and the costs of procuring raw materials. In this study, the variables are: the use of raw materials, inventory of raw materials (economic order quantity), re-order point (ROP) and Grand Total Cost (TC). Bill of Material of SISCO brand shown on Figure 1.

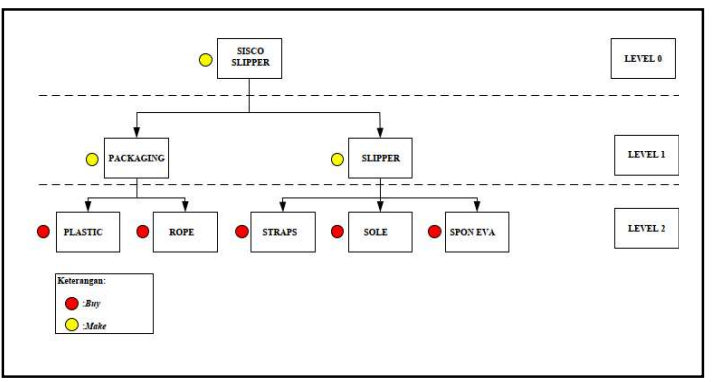

Fig. 2. Bill of Material of SISCO line production

\subsection{Data collection Methods}

\subsubsection{Interview data collection Method}

This interview data collection technique conducting by direct interviews with competent employees and have mature about data needed in this research. Based on this technique, we expect data about general company activity and the costs that affect inventory of raw materials or other related data in this research.

\subsubsection{Documentation data collecting Method}

On this research data collection from factorization and explanation through document or archive sources. Based on this data we can estimates raw materials, inventory costs, raw materials consumption, safety stock and reorder

\subsection{Data processing}

Data processing in this study starts from determining the number of sales of goods that will come by using the forecasting method. Then determine the amount of raw materials ordered in one order with the EOQ method. Based on EOQ, we can determine the reorder time (ROP) and determine the Grand total cost (TC)

\section{Result}

After got data from interviewing crew in SISCO brand based on data collection methods, we have data selling per month of SISCO slippery product during one year. Selling data of SISCO product shown on Table 1.

Table 1. SISCO product demand during 2019.

\begin{tabular}{|c|c|c|c|}
\hline Month & $\begin{array}{c}\text { Selling data } \\
\text { per month }\end{array}$ & Month & $\begin{array}{c}\text { Selling data } \\
\text { per month }\end{array}$ \\
\hline January & 641 & July & 1252 \\
\hline February & 564 & August & 355 \\
\hline March & 732 & September & 473 \\
\hline April & 720 & October & 671 \\
\hline May & 633 & November & 928 \\
\hline June & 524 & December & 1068 \\
\hline
\end{tabular}

We also had data about Material cost, major ordering and lead time for each material. Shown on Table 2.

Table 2. Material requirement and price for single batch production.

\begin{tabular}{|c|c|c|c|}
\hline Month & $\begin{array}{c}\text { Material } \\
\text { cost (IDR) }\end{array}$ & $\begin{array}{c}\text { Major } \\
\text { Ordering } \\
\text { cost (pc) }\end{array}$ & $\begin{array}{c}\text { Lead } \\
\text { Time } \\
\text { (hours) }\end{array}$ \\
\hline $\begin{array}{c}\text { Eva } \\
\text { Spon/sheet }\end{array}$ & 95.000 & 10.000 & 4 \\
\hline Sole/sheet & 14.000 & 10.000 & 4 \\
\hline $\begin{array}{c}\text { Glue/18 } \\
\text { litre }\end{array}$ & 270.000 & 10.000 & 4 \\
\hline $\begin{array}{c}\text { Straps/score } \\
\text { Plastic/score }\end{array}$ & 25.000 & 10.000 & 4 \\
\hline \multicolumn{2}{|l}{14.000} & 10.000 & 4 \\
\hline
\end{tabular}

\section{Dicussion}

Based on this data on table 1 and 2 we to predict demand of slippery of SISCO brand aided with three methods, they are moving average, single exponential smoothing, and double exponential smoothing. Moving average using MA-3 to avoiding data lagging or error during forecasting. Demand of SISCO brand has shown on table 3.

\subsection{Time Series Methods Forecasting}

Result of time series forecasting shown on table 3. 
Table 3. Time series forecasting

\begin{tabular}{|l|l|l|l|l|}
\hline Mo & \multirow{2}{*}{$\begin{array}{l}\text { Actual } \\
\text { dath }\end{array}$} & \multicolumn{3}{|l|}{ Forecast methods } \\
\cline { 3 - 5 } & 3- MA & SES & DES \\
\hline 1 & 641 & & 641 & 641 \\
\hline 2 & 564 & & 641.00 & 256.40 \\
\hline 3 & 732 & & 625.60 & 410.16 \\
\hline 4 & 720 & 644 & 646.88 & 485.90 \\
\hline 5 & 633 & 672 & 661.50 & 428.46 \\
\hline 6 & 524 & 695 & 655.80 & 375.93 \\
\hline 7 & 1252 & 626 & 629.44 & 298.44 \\
\hline 8 & 355 & 803 & 753.95 & 1072.93 \\
\hline 9 & 473 & 710 & 674.16 & -288.76 \\
\hline 10 & 671 & 693 & 633.93 & 646.26 \\
\hline 11 & 928 & 500 & 641.34 & 283.25 \\
\hline 12 & 1068 & 691 & 698.68 & 758.05 \\
\hline & & 889 & 772.54 & 613.17 \\
\hline
\end{tabular}

Based on data from table 3 we analysed Mean Square Error (MSE) forecasting performed using moving average, single exponential smoothing, and double exponential smoothing methods. The MSE data shown on table 4 .

Table 4. Font styles for a reference.

\begin{tabular}{|c|c|c|c|}
\hline Instrument & MA-3 & SES & DES \\
\hline MAD & 269 & 212.05 & 420.80 \\
\hline MSE & 112440.07 & 77085.08 & 257647.66 \\
\hline MAPE & 0.40 & 0.31 & 0.67 \\
\hline
\end{tabular}

Based on the table described above, the smallest MSE in this slippery product performed by SES method. based on this data, we can perform demand data for the next period. The following is the data for forecasting the slippery product 772.54 round up to 773 .

\subsection{Raw Materials Availability}

Based on orders from suppliers, the amount of raw material availability in small businesses with SISCO brand sandals, data obtained from the results of research on the number of raw materials that can be available by the company per month to produce each product shown in the table 4.

Table 4. Font styles for a reference.

\begin{tabular}{|c|c|c|c|c|}
\hline \multirow{2}{*}{$\begin{array}{c}\text { Raw } \\
\text { Material }\end{array}$} & \multirow{2}{*}{$\begin{array}{c}\text { Market } \\
\text { Demand }\end{array}$} & \multicolumn{3}{|c|}{ Raw Material } \\
\cline { 3 - 5 } & & Demand & Per pc & $\begin{array}{c}\text { in } \\
\text { inventory }\end{array}$ \\
\hline Eva Spon & 773 & 20 & 40 & 25 sheets \\
\hline Sole & 773 & 52 & 15 & 75 sheets \\
\hline Glue & 773 & 4 & 250 & 72 lt \\
\hline Straps & 773 & 39 & 20 & 50 score \\
\hline Plastic & 773 & 39 & 20 & 50 score \\
\hline
\end{tabular}

From the data in table 4, we can see the amount of raw material availability for each month is larger than the number of requests for raw materials for each month. Therefore, we adjust the number of raw material requirement to be manufactured from the forecasting perform using Economic Order Quantity (EOQ) and ReOrder Point (ROP). EOQ flown using Equation[10], [11]

$$
E O Q=\sqrt{\frac{2 D S}{H}}
$$

Where; $\mathrm{D}=$ total raw materials; $\mathrm{S}=$ Major ordering cost; $\mathrm{H}=$ Storage cost

Table 5. Result of EOQ.

\begin{tabular}{|c|c|c|c|c|}
\hline $\begin{array}{c}\text { Raw } \\
\text { Material }\end{array}$ & D & S & H & EOQ \\
\hline Eva Spon & 20 & 10,000 & 792 & 22 \\
\hline Sole & 52 & 10,000 & 117 & 94 \\
\hline Glue & 4 & 10,000 & 2250 & 6 \\
\hline Straps & 39 & 10,000 & 208 & 61 \\
\hline Plastics & 39 & 10,000 & 117 & 82 \\
\hline
\end{tabular}

ROP flown using equation[8].

$$
R O P=\left(\frac{D}{t}\right) L
$$

Where; $\mathrm{D}=$ total raw materials; $\mathrm{t}=$ Active work hour per week); $\mathrm{L}=$ lead time

Result of ROP shown on table 5

Table 6. Result of ROP

\begin{tabular}{|c|c|c|c|c|c|}
\hline $\begin{array}{c}\text { Raw } \\
\text { Material }\end{array}$ & D & t & $\begin{array}{c}\text { ROP } \\
\text { (Day) }\end{array}$ & L & $\begin{array}{c}\text { ROP } \\
\text { (unit) }\end{array}$ \\
\hline Eva Spon & 20 & 26 & 0.77 & 4 & 3 \\
\hline Sole & 52 & 26 & 2.00 & 4 & 8 \\
\hline Glue & 4 & 26 & 0.15 & 4 & 1 \\
\hline Straps & 39 & 26 & 1.50 & 4 & 6 \\
\hline Plastics & 39 & 26 & 1.50 & 4 & 6 \\
\hline
\end{tabular}

Based of data on table 5 and table 6 we estimate total ordering cost. Result of Grand total cost per month for SISCO brand SME during slippery production shown on Table 7.

\begin{tabular}{|c|c|c|c|c|}
\hline $\begin{array}{c}\text { Raw } \\
\text { Material }\end{array}$ & $\begin{array}{c}\text { Ordering } \\
\text { Cost }\end{array}$ & $\begin{array}{c}\text { Holding } \\
\text { Cost }\end{array}$ & $\begin{array}{c}\text { Raw } \\
\text { material } \\
\text { ordering } \\
\text { cost }\end{array}$ & $\begin{array}{c}\text { Total } \\
\text { Cost } \\
\text { (IDR) }\end{array}$ \\
\hline Eva Spon & 9091 & 8712.00 & $\begin{array}{c}1,900,00 \\
0\end{array}$ & $\begin{array}{c}1,917,8 \\
02.91 \\
\end{array}$ \\
\hline Sole & 5532 & 5499.00 & 728,000 & $\begin{array}{c}739,03 \\
0.91\end{array}$ \\
\hline Glue & 6667 & 6750.00 & $\begin{array}{c}1,080,00 \\
0\end{array}$ & $\begin{array}{c}1,093,4 \\
16.67\end{array}$ \\
\hline Straps & 6393 & 6344.00 & 975,000 & $\begin{array}{c}987,73 \\
7.44\end{array}$ \\
\hline Plastics & 4756 & 4797.00 & 546,000 & $\begin{array}{c}555,53 \\
2.10\end{array}$ \\
\hline \multicolumn{4}{|c|}{ Grand Total Cost } & $\begin{array}{c}5,293,5 \\
41.03\end{array}$ \\
\hline
\end{tabular}

Table 7. Result of Grand total cost per month 


\section{Conclusion}

On this research applied three time series forecasting they are forecasting performed using moving average, single exponential smoothing, and double exponential smoothing methods. The lowest Mean Square Error is Single Exponential Smoothing with value 77085.08. The most crucial raw material stock is ROP count is Glue, it will be ruined out in 1hour and 12 minutes during process. raw material and grand total od production 773 pairs of slippery in SISCO Brand SME is IDR 5,293,541.03

Thank for DIPA Fakultas Teknik 2021 to founding this publication.

\section{References}

[1] J. Mendy, "Performance management problem of four small and medium-sized enterprises (SMEs): towards a performance resolution," $J$. Small Bus. Enterp. Dev., vol. 28, no. 5, pp. 690710, Jan. [2021], doi: 10.1108/JSBED-06-20190201 .

[2] D. Yuzaria, E. Rahmi, and M. I. Rias, "Increasing the Competitiveness of Micro, Small and Medium Enterprises of Skin Crackers in Padang City West Sumatra Province Indonesia," \{IOP\} Conf. Ser. Earth Environ. Sci., vol. 757, no. 1, p. 12014, May [2021], doi: 10.1088/1755-1315/757/1/012014.

[3] M. I. Nasution, M. Fahmi, Jufrizen, Muslih, and M. A. Prayogi, "The Quality of Small and Medium Enterprises Performance Using the Structural Equation Model-Part Least Square ( $\{\mathrm{SEM}\}-\{\mathrm{PLS}\})$, J J. Phys. Conf. Ser., vol. 1477, p. 52052, Mar. [2020], doi: 10.1088/1742-6596/1477/5/052052.

[4] E. R. Lestari, F. L. Ardianti, and L. Rachmawati, "Firm performance model in small and medium enterprises ( $\{$ SMEs $\}$ ) based on learning orientation and innovation," $\{I O P\}$ Conf. Ser. Earth Environ. Sci., vol. 131, p. 12027, Mar. [2018], doi: 10.1088/17551315/131/1/012027.

[5] R. B. Yosan, M. Kholil, and B. Hanum, "Implementation of Inventory Management System (IMS) case study on XYZ online store business unit," IOP Conf. Ser. Mater. Sci. Eng., vol. 343, p. 12022, [2018], doi: 10.1088/1757899x/343/1/012022.

[6] D. M. Ikasari, E. R. Lestari, and E. Prastya, "Inventory control of raw material using silver meal heuristic method in PR. Trubus Alami Malang," IOP Conf. Ser. Earth Environ. Sci., vol. 131, p. 12024, [2018], doi: 10.1088/17551315/131/1/012024.

[7] Suhartono, S. P. Rahayu, D. D. Prastyo, D. G. P. Wijayanti, and Juliyanto, "Hybrid model for forecasting time series with trend, seasonal and salendar variation patterns," J. Phys. Conf. Ser., vol. 890, p. 12160, Sep. [2017], doi:

\subsection{8/1742-6596/890/1/012160.}

[8] M. Heaviside, B. Mulyawan, and T. Sutrisno, "Determination of minimum stock on system retail using forecast, economic order quantity and reorder point methods," IOP Conf. Ser. Mater. Sci. Eng., vol. 1007, no. 1, pp. 1-7, [2020], doi: 10.1088/1757899X/1007/1/012180.

[9] S. W. Chan, R. Tasmin, A. H. Nor Aziati, R. Z. Rasi, F. B. Ismail, and L. P. Yaw, "Factors Influencing the Effectiveness of Inventory Management in Manufacturing SMEs," IOP Conf. Ser. Mater. Sci. Eng., vol. 226, p. 12024 , [2017], doi: 10.1088/1757-899x/226/1/012024.

[10] R. Setiawan, "Economic order quantity (EOQ) by game theory approach in probabilistic supply chain system under service level constraint for items with imperfect quality," J. Phys. Conf. Ser., vol. 983, p. 12065, [2018], doi: 10.1088/1742-6596/983/1/012065.

[11] E. Hertini, N. Anggriani, W. Mianna, and A. K. Supriatna, "Economic Order Quantity (EOQ) Optimal Control Considering Selling Price and Salesman Initiative Cost," IOP Conf. Ser. Mater. Sci. Eng., vol. 332, p. 12013, [2018], doi: 10.1088/1757-899x/332/1/012013. 